\title{
"Transformation of the Ukrainian banking system regulation: a new horizon of compliance with the international framework"
}

\begin{tabular}{|c|c|}
\hline AUTHORS & $\begin{array}{l}\text { Lyubov Khudoliy iD https://orcid.org/0000-0002-1628-068X } \\
\text { Oleg Bronin iD https://orcid.org/0000-0001-5937-2130 }\end{array}$ \\
\hline ARTICLE INFO & $\begin{array}{l}\text { Lyubov Khudoliy and Oleg Bronin (2019). Transformation of the Ukrainian } \\
\text { banking system regulation: a new horizon of compliance with the international } \\
\text { framework. Banks and Bank Systems, 14(4), 22-33. } \\
\text { doi:10.21511/bbs.14(4).2019.03 }\end{array}$ \\
\hline DOI & http://dx.doi.org/10.21511/bbs.14(4).2019.03 \\
\hline RELEASED ON & Thursday, 28 November 2019 \\
\hline RECEIVED ON & Monday, 30 September 2019 \\
\hline ACCEPTED ON & Tuesday, 19 November 2019 \\
\hline LICENSE & $\begin{array}{l}(\boldsymbol{( c )} \overline{\mathrm{EY}} \\
\text { This work is licensed under a Creative Commons Attribution } 4.0 \text { International } \\
\text { License }\end{array}$ \\
\hline JOURNAL & "Banks and Bank Systems" \\
\hline ISSN PRINT & $1816-7403$ \\
\hline ISSN ONLINE & $1991-7074$ \\
\hline PUBLISHER & LLC "Consulting Publishing Company "Business Perspectives" \\
\hline FOUNDER & LLC "Consulting Publishing Company "Business Perspectives" \\
\hline
\end{tabular}

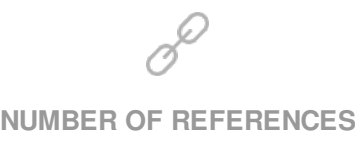

27

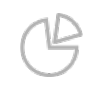

NUMBER OF FIGURES

2

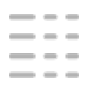

NUMBER OF TABLES

2

(C) The author(s) 2022. This publication is an open access article. 


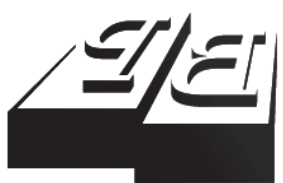

BUSINESS PERSPECTIVES

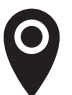

LLC "CPC "Business Perspectives" Hryhorii Skovoroda lane, 10, Sumy, 40022, Ukraine

www.businessperspectives.org

Received on: $30^{\text {th }}$ of September, 2019 Accepted on: $19^{\text {th }}$ of November, 2019

(c) Lyubov Khudoliy,

Oleg Bronin, 2019

Lyubov Khudoliy, Doctor of Economics, Professor, Head of the Department of Banking and Insurance, National University of Life and Environmental Sciences of Ukraine, Ukraine.

Oleg Bronin, Ph.D., Associate Professor, Department of Banking and Insurance, National University of Life and Environmental Sciences of Ukraine, Ukraine.

\section{() (i)}

This is an Open Access article, distributed under the terms of the Creative Commons Attribution 4.0 International license, which permits unrestricted re-use, distribution, and reproduction in any medium, provided the original work is properly cited.

\section{TRANSFORMATION \\ OF THE UKRAINIAN BANKING SYSTEM REGULATION: A NEW HORIZON OF COMPLIANCE WITH THE INTERNATIONAL FRAMEWORK}

\begin{abstract}
This article discusses the latest methodological recommendations of the Basel Committee on Banking Supervision developed in response to the effects of the global financial crisis and known as Basel III. The purpose of the study is to explore scientific approaches to justifying bank regulation as a key condition for overcoming the economic crisis and improving financial sustainability. The object of research is Basel III instruments that will be implemented in the bank regulatory policy of Ukraine. The systematic approach and systemic thinking used in the article allow one to substantiate the expediency of Ukrainian banking institutions' governance based on the riskoriented approach and to determine the strategy of bank supervision for the next 1-3 years. The study evaluates the results of stress testing of the largest banks in Ukraine. Thus, the results confirm that the banking sector in Ukraine is sufficiently capitalized in the absence of macroeconomic shocks, but in case of a crisis, some of these banks are not protected. Therefore, the article formulates recommendations for improving the regulation of these banks, the phased implementation of Basel III, the application of new principles, standards, tools and methods, corporate governance and risk management in Ukrainian banks.
\end{abstract}

\section{Keywords \\ banks, monetary policy, crises, stability, regulation \\ JEL Classification E52, G01, G21}

\section{INTRODUCTION}

Over the past five years, the situation in the Ukrainian banking sector has changed dramatically. Over 100 banks become insolvent. The share of state-owned banks in the market has become dominant. Millions of depositors have lost their savings. The economic losses owing to the crisis exceeded $40 \%$ of GDP. The public confidence in banking institutions has shaken. This requires rethinking of the regulation mechanism of the banking sector in Ukraine, which was unable to withstand financial risks, and the development of a new, more effective mechanism for increasing banking stability. To address the challenges of the financial crisis, the central banks of the leading world countries have thoroughly revised a number of basic principles concerning banking system governance. Since, according to the program documents, Ukraine has undertaken to align its banking legislation with international standards. So, it is necessary to analyze the main Basel III innovations to determine the possibility of their adaptation to the features of the domestic banking sector, to determine their possible impact on Ukrainian banking institutions, to develop a plan for the introduction of new principles, standards and methods in Ukraine. 


\section{THEORETICAL BASIS}

Banking regulation issues, the Basel Committee on Banking Supervision standards, and their impact on banking institutions have been extensively researched by well-known scholars such as Allen and Gale (2000), Barth, Caprio, and Levine (2001), Goodhart (2018) and leading professionals of the global financial institutions.

Heyets (2016), Kozmenko and Vasyl'eva (2009) researched the banking regulation issues in Ukraine. However, due to the dramatic changes that have recently taken place in the Ukrainian banking sector, there is a need to improve banking regulation through the lens of Basel III recommendations.

The global financial crisis has forced a rethinking of the architecture of global financial regulation. According to the IMF (2018), "New standards, tools and methods have been developed, and their implementation has started in different countries around the world". The disadvantages of previous banking regulation reforms known as Basel I and Basel II were that they aimed to ensure the stability of the banking sector without taking into account its relationship with the present state, trends and challenges of the macro environment, and bank risk management was carried out only on a short-term basis. Flamee and Windels (2009), while analyzing the restructuring financial sector supervision, state that valuable insights could be gained from a comparison of the regulatory systems for banking and insurance. In terms of the potential impact of Basel II, two areas have been extensively discussed, namely, the pro-cyclical effects (Benford \& Nier, 2007) and the impact on the availability and price of credit to small and medium enterprises (Altman \& Sabato, 2005). For instance, Ruthenberg and Landskroner (2008) analyze and estimate the possible impact of Basel II on the pricing of bank loans. Thakor (1996) proved the impact of capital requirements on bank lending activities. A new line of research into credit models for monetary policy has considered the association between bank capital and loan demand and supply (Van den Henvel, 2002).

In terms of Basel III, references in the scientific literature are scarce, since these regulations have only recently been adopted. Angelini et al. (2011) study the impact of Basel III on long-term economic performance as well as fluctuations in economic performance, while Blundell-Wignall and Atkinson (2010) critically analyze the Basel III proposals and find some useful elements but also raise some major concerns.

Basel III, which is mandatory for implementation in EU countries and is gradually being implemented in Ukraine, aims to increase the ability of the banking sector to withstand financial stress; improve corporate governance and, in particular, risk management system; to expand the list of public information on banks' activities, which will increase their credibility.

The role of capital in the protection of a bank remains crucial, as it is capital that provides a buffer against the peak losses that exceed the expected level of credit losses. Peak losses do not occur annually, it is difficult to predict in advance the moment of their onset and amount, but they can be very significant. Expected credit losses, on the contrary, are components of current expenses and they need to be included in the cost of credit products. In the worst case, one can assume that the entire loan portfolio of the bank ceases to be served; however, this is unlikely, and it is economically unfeasible to form reserves for the entire loan portfolio in advance (BCBS, 2019). Therefore, the Basel documents are logically seeking a balance between the benefits of increased capitalization and the cost of maintaining the capital represented by the formula: regulatory capital adequacy ratio equals regulatory capital divided by assets weighted for credit, market and operational risks.

In December 2017, the Basel Committee decided to establish and gradually increase the denominator by the amount of risk-weighted assets obtained using a standardized approach. To calculate capital ratios, the greater of two values is used: risk-weighted assets according to an approach based on internal ratings and $72.5 \%$ risk-weighted assets according to a standardized approach. The limit will increase in five years from $50 \%$ to $72.5 \%$ of risk-weighted assets, according to the standardized approach (BCBS, 2018). Due to the technical complexity of compliance with the standardized approach, its implementation in the world is still 
postponed. New capital requirements to cover market risk may be delayed until 2022.

Until the global 2007-2009 financial crisis, the Basel Committee did not focus on liquidity; therefore, the quality requirements to liquidity risk management were not taken into account in policies then in force. Additional capital requirements were also not envisaged in case of inappropriate liquidity management. The crisis has brought awareness that liquidity sufficiency is no less important than capital sufficiency. The additional liquidity monitoring tools have been introduced. Liquidity Coverage Ratio (LCR) shows that high-quality liquid assets should exceed net cash outflow in 30 days (BCBS, 2013). Net Stable Funding Ratio (NSFR) shows that available amount of stable financing should exceed required amount of stable funding (BCBS, 2014). Currently, 45 countries have fully implemented the LCR through EU legislation or national regulations. NSFR was introduced globally in 2018, but the EU has not yet adopted the relevant regulations.

\section{RESULTS}

In the period of 2009 to 2019, Ukraine also went through two deep banking crises, which caused significant losses for the economy. According to experts, fiscal expenditures for overcoming the 2007-2009 crisis amounted to 5\% of GDP, and the 2014-2016 crisis - 16\% of GDP. Total losses of the economy reached $40 \%$ of GDP. These figures show how high was the cost of improper banking sector regulation.

In 2018 , to ensure the financial stability of the banking sector and make it more resilient to shocks and crises, the National Bank of Ukraine developed the Macroprudential Policy Strategy. This is a high-level document defining strategic and intermediate goals, principles, approaches, a list of instruments in the banking system regulation field (NBU, 2018a).

According to the authors, there are following systemic risks in the Ukrainian banking sector at this stage:

- $\quad$ state monopoly in the banking system;

- high proportion of non-performing assets;
- weak protection of the creditors' rights;

- high dollarization;

- $\quad$ short-term funding base of banks;

- significant maturity gaps between assets and liabilities;

- rapid growth of consumer lending;

- reduction of corporate lending;

- inflow of assets and operations into the non-banking financial sector.

To prevent and reduce risks, in accordance with the Basel Committee recommendations in Ukraine, some macroprudential tools should be implemented (see Table 1).

According to the NBU (2018d), "The National Bank made transition to a new bank evaluation in carrying out the banking supervision "Supervisory review and evaluation process" (SREP) based on the risks assessment and quality of management of those risks in the bank (risk-based approach)". The assessment using the risk-based approach has become continuous and is implemented simultaneously by all banks through assessing the size of risks and the quality of their management, analyzing current trends in the banks' activities, in particular, with comparing the key performance indicators of a bank with a "peer group" of similar banks. The assessment of banks is carried out annually on January 1 and is updated quarterly based on an analysis of changes in quantitative indicators and taking new information into account. According to the assessment results, the strategy of the bank supervision is defined, which takes into account the need for early intervention measures, the bank's viability for the next 12 months and its stability for the next three years, capital sufficiency and liquidity to cover the risks, state of the corporate governance, and need for inspection.

The introduction of the banks' SREP assessment has had the following implications for Ukrainian banks:

- all prudential departments were consolidated to determine a common strategy for the bank supervision;

- prudential resource efficiency increases depending on the level of risk and systemic impact of each bank; 
Table 1. Macroprudential tools to reduce systemic risks in the banking sector of Ukraine

\begin{tabular}{|c|c|}
\hline Tool name & A brief description of the tool \\
\hline \multicolumn{2}{|r|}{ Capital instruments } \\
\hline Capital Conservation Buffer & $\begin{array}{l}\text { Formed in a non-stress period for covering losses and preventing the minimum } \\
\text { requirements for capital sufficiency. Will be launched in } 2020 \text { and amount to } 0.625 \% \\
\text { of the capital with a phased increase of up to } 2.5 \%\end{array}$ \\
\hline Countercyclical Capital Buffer & $\begin{array}{l}\text { Introduced during the period of credit activity, cancelled during economic recession } \\
\text { periods. Depending on the phase of the economic cycle, may range from } 0 \% \text { to } 2.5 \% \\
\text { of capital }\end{array}$ \\
\hline Buffer for Systemically Important Banks & Established for systemically important banks in the amount of $1-2 \%$ of capital \\
\hline Systemic Risk Buffer & $\begin{array}{l}\text { Reduces vulnerability to long-term non-cyclic systemic risks. Not yet provided for by } \\
\text { the NBU }\end{array}$ \\
\hline Leverage Ratio & $\begin{array}{l}\text { Ratio of the first-tier capital to the non-risk-weighted assets. Planned to be } \\
\text { introduced in the future }\end{array}$ \\
\hline Additional risk weights for certain types of loans & $\begin{array}{l}\text { Increase in capital to cover possible losses for certain types of loans, e.g., for foreign } \\
\text { currency loans }\end{array}$ \\
\hline \multicolumn{2}{|r|}{ Liquidity instruments } \\
\hline Liquidity Coverage Ratio & $\begin{array}{l}\text { The ratio determine show much high-quality liquid assets a bank must have to cover } \\
\text { net outflow of funds within } 30 \text { days during a crisis. Introduced in December } 2018\end{array}$ \\
\hline Net Stable Funding Ratio (NSFR) & $\begin{array}{l}\text { The ratio determines the required amount of long-term financing depending on the } \\
\text { maturity of assets. Planned to be introduced in } 2020\end{array}$ \\
\hline \multicolumn{2}{|r|}{ Other tools } \\
\hline Loan-To-Value Ratio (LTV) & $\begin{array}{l}\text { Limits the maximum loan amount depending on the value of collateral. Not planned } \\
\text { to be introduced in the near future; will possibly be advisory in nature }\end{array}$ \\
\hline Debt Service-To-Income Ratio (DSTI) & \multirow{2}{*}{$\begin{array}{l}\text { Limits the maximum loan amount depending on the borrower's income. Not } \\
\text { planned to be introduced in the near future; will possibly be advisory in nature }\end{array}$} \\
\hline Debt-To-Income Ratio (DTI) & \\
\hline $\begin{array}{l}\text { Increased requirements for disclosure of public } \\
\text { information about the bank }\end{array}$ & $\begin{array}{l}\text { Raises awareness of investors and clients about the activities of banks. Contributes } \\
\text { to the restoration of trust to banks. The list of information obligatory to be disclosed } \\
\text { is constantly expanding }\end{array}$ \\
\hline
\end{tabular}

- the approaches to assessing banks are brought in line with international law, which enables comparing Ukrainian banks with those in other countries;

- the response at the early stages of identifying the bank risks is improved.

Another innovation was the annual evaluation of banks' stability, and for the largest banks - stress testing involving modeling an unfavorable macroeconomic scenario. Assessment of banks' stability was included in the regulatory practice of the leading world central banks, which allows preventing the accumulation of systemic risks and preparing for possible financial crises (NBU, 2017).

In 2018, the National Bank of Ukraine has completed the banking sector stability assessment. The procedure was carried out in three stages. At the first stage, external auditors estimated asset quality and eligibility of collateral for all banks. The analysis showed that banks considered expected losses and formed reserves not to the full extent.
At the second stage, which was conducted in the event of detecting an incorrect reflection of the quality of assets by the banks at the first stage, capital sufficiency and requirement were assessed. Finally, at the third stage, stress testing, the largest banks were selected by the average of two indicators: risk-weighted assets and deposits of individuals. 24 banks collectively accounting for more than $90 \%$ of banking sector assets got into the group. Stress testing involves assessing bank performance indicators, testing the impact of adverse events on those indicators and identifying measures necessary to increase banks' resilience to those adverse events.

To test the impact of the crisis on banks, in addition to the baseline scenario, at least one adverse scenario is developed, which is not a prognosis and does not reflect the central bank's expectations regarding economic development for the nearest period, but is built based on hypothetical assumptions of macroeconomic indicators that lead to the actualization of certain risks in substantial volumes (EBA, 2018). For example, in the USA, according to an adverse scenario, real GDP 
Table 2. Baseline and adverse scenarios for 2019-2021

Source: Actual values and official forecasts of the NBU.

\begin{tabular}{|c|c|c|c|c|c|c|c|}
\hline \multirow{2}{*}{ Indicators } & \multirow{2}{*}{2018} & \multicolumn{3}{|c|}{ Baseline scenario } & \multicolumn{3}{|c|}{ Adverse scenario } \\
\hline & & 2019 & 2020 & 2021 & 2019 & 2020 & 2021 \\
\hline Real GDP, \% & 3.4 & 2.5 & 2.9 & 3.7 & -4.1 & -3.7 & 1.0 \\
\hline Nominal GDP, \% & 19.1 & 11.6 & 9.4 & 9.4 & 17.6 & 13.3 & 11.4 \\
\hline Consumer Price Index, \% & 9.8 & 6.3 & 5.0 & 5.0 & 15.8 & 14.8 & 8.8 \\
\hline Hryvnia to the USD, \% & -2.2 & -7.5 & -3.3 & -1.0 & -23.2 & -11.1 & -4.1 \\
\hline
\end{tabular}

in the peak of the crisis is expected to fall by 3.5\%, and by $8.9 \%$ according to an extremely adverse scenario. In the EU countries, the crisis, according to an adverse scenario, lasts for two years and results in a GDP decline by $2 \%$ on average and up to $6 \%$ in certain countries. In the UK, the adverse scenario implies a 5\% GDP reduction during the first year and a devaluation of the pound sterling against the euro by $26 \%$.

In Ukraine, for the baseline and adverse scenarios, the following predictions were used (Table 2).

According to stress testing, the banking sector is sufficiently capitalized in the absence of macroeconomic shocks. According to the baseline scenario of economic development, capital of banks grows at the expense of profits. However, 12 out of the 24 banks turned out insufficiently protected in the event of a crisis. These banks have to restructure their balances or increase their capital. Credit risk remains high: banks lack qualitative corporate borrowers; demand exists only for consumer loans. The share of non-performing loans decreases very slowly. The level of coverage of non-performing loans with reserves is $87 \%$, approaching the prudential requirements. The concentration of risks in consumer lending requires an increase in the requirements for assessing the credit risks of individual borrowers. Non-banking financial institutions so far do not pose a significant risk to banks. Liquidity risk increased due to a decrease in the amount of high-quality liquid assets in the balance sheets of banks. This being said, large banks have a substantial liquidity cushion. The funding structure in banks is invariably short; the maturity gap between assets and liabilities puts banks at risks. Currency risk remains at an average level, since the level of dollarization of the balances of some banks, especially state-owned ones and those with Ukrainian capital, is still significant. Risk of profitability has declined (after four unprofitable years, the banking sector has gained profit) due to the sufficient operating profit of banks, especially those with foreign capital; meanwhile, state banks still have low operational efficiency. Legal risk has declined due to adoption of several laws for banking business development.

Based on these findings, the following recommendations were given to the banks:

to intensify work with non-performing loans;

- to assess adequately the credit risks of borrowers;

- for banks that have losses - to review business models;

- to sell non-core assets acquired during the crisis;

- to reduce loan portfolio dollarization;

- to utilize the possibilities of the NBU Credit Register for the credit risk assessment;

- to reach the LCR ratio by the end of 2019;

- to endeavor to attract more long-term resources;

- to ensure timely and complete execution of additional capitalization programs.

In 2019, 29 banking institutions accounting for 93\% of the assets of the banking system have to undergo stress testing. The main issue of stress testing will be the analysis of the consumer loan portfolio, which has been substantially increasing over recent years. Currently, the risks associated with that are uncritical; however, lowering the lending standards can have negative consequenc- 
Current liquidity ratio $\mathrm{H} 5$

Highly liquid assets +

Other undue assets up to 31 days
Liabilities
up to 31 days

Liquidity coverage ratio LCR

High-quality liquid assets

$\begin{array}{cc}\text { Outflow } & \text { Income } \\ \text { for liabilities } & -\quad \\ \text { from assets } & \\ \text { up to } 30 \text { days } & \text { up to } 30 \text { days }\end{array}$

Figure 1. Comparison of current liquidity ratio $\mathrm{H} 5$ and liquidity coverage ratio LCR

es. In the adverse scenario, a severe deterioration in the quality of loans issued to individuals is foreseen. There will also be more rigorous assumptions about the dynamics of interest spread and net interest margin.

In general, the effect of stress testing is in creating a safety margin of the banking system to overcome possible crisis events, formation of banks' awareness of their own risk of activity and encouraging them to create an effective risk management system, working out a common understanding of the challenges and threats to the banking business, raising the level of financial stability of the banking sector as a whole.

A significant impact on the assessment of the banking sector stability was the fact that in 2018 the Ukrainian banking system has shifted to the new international financial reporting standard, IFRS 9. Research by IASB (2012) supports IFRS 9 by introducing a new model for assessing credit losses - not incurred, as it was before the new standard introduction, but expected based on potential risks.

The banking sector was switching to IFRS 9 in phases: first, a three-month transitional period began during which the banks' influence measures were not applied to the banks for violations caused by change in the valuation of financial instruments. This transitional period was then extended to the end of June so that banks could gradually adapt to the preparation of interim reporting. As a result, despite the fear that a new standard of reporting will lead to the need for additional capitalization, no significant problems in the banking sector have arisen. Overall, the introduction of IFRS 9 in Ukraine increases the confidence of international investors in the financial reporting of the Ukrainian banking system and will encourage banks to be more responsible and more cautious to the risks.

In 2018, based on Basel III, the National Bank of Ukraine introduced the first macroprudential instrument, namely, Liquidity Coverage Ratio (LCR). Why does Ukraine need this ratio? First, the country has committed itself to comply with European legislation. Second, as a result, the efficiency of regulatory requirements increases and the system of liquidity risk management in Ukrainian banks is improved. And third, this standard is prevalent in the world of liquidity metrics; this is clear to international investors and partners. LCR establishes the minimum required level of liquidity to cover the net funds outflow from the bank during 30 days, taking into account the stress scenario. Unlike the current liquidity ratio H5 (see Figure 1), which is a profile of the balance sheet as of the reporting date and does not take into account that not all deposits will be taken from the bank, but also not all loans will be repaid in time, LCR simulates the liquidity position of the bank under realistic liquidity stress.

Introduction of LCR in Ukraine has its own peculiarities. Given the undeveloped stock market in Ukraine, shortcoming high-quality liquid securities, especially in foreign currency, at the introduction of the LCR, one asset level was considered instead of three, an exhaustive list of high-quality liquid assets was defined, bonds of an internal state loan are accounted by value, for which they are accepted as collateral for refinancing loans.

Given the inability to quickly and in large volumes buy currency on the interbank foreign exchange market of Ukraine to cover outflows in foreign currency, foreign currency bonds of an internal 
state loan with a maturity of up to 30 days are accounted for as hryvnia assets, LCR requirements are set not only in all currencies, but also in foreign currency.

Since the Ukrainian criteria for stability of retail deposits are irrelevant to the European ones, in the LCR calculation, stable and less stable deposits are replaced with fixed-term and on-demand deposits.

The Basel Committee has developed the LCR based on the 2007-2009 crisis scenario; in contrast, Ukraine has survived the most stressful scenario in 2014-2016, so the National Bank of Ukraine used its own calibration of outflow coefficients.

Another feature of introducing LCR in Ukraine is the legal ban on lending to individuals in foreign currency, so the revenue ratio is set at $100 \%$ instead of 50\%; that is, all income supplements the bank's liquidity, and is not aimed at issuing new loans.

In Ukraine, the LCR was introduced in stages. In February 2018, the Board of the NBU adopted the corresponding regulatory acts. From June to December 2018, LCR was calculated in the test mode. Based on the results of the test calculations, a quantitative analysis of the LCR influence on the banks was conducted, and the timetable to achieve the $100 \%$ of the LCR was determined. From December 1, 2018, banks calculate the LCR liquidity ratio daily. Reference values of LCR for all currencies and in foreign currencies must be not less than 80 percent for LCR for all currencies and 50 percent for LCR in foreign currency from December 31st, 2018; 90 percent from June 1st, 2019; and 100 percent from December 1st, 2019.

The second macroprudential instrument - Net Stable Funding Ratio (NSFR) - is still under development. Unlike the LCR, it is a structural, not a stress indicator. At the global level, NSFR is more difficult to implement than LCR. While international banks lack 1.9 billion euros to implement the LCR, they lack 20.1 billion euros to implement NSFR. The introduction of NSFR is delayed in the EU due to many controversial issues. For example, whether derivatives should be taken into account in calculations or not. In Ukraine, the introduc- tion of NSFR will take place not earlier than the third quarter of 2019. This being said, a long period of its application in test mode is envisaged.

What are the next steps in reforming the liquidity management system? It is planned to replace the $\mathrm{H} 5$ ratio by LCR, and $\mathrm{H} 6$ by NSFR. In addition, important attention will be paid to liquidity monitoring tools (analysis of liabilities' concentration, GAP analysis, i.e. liquidity gaps arising from the difference in maturity between claims and liabilities); bank liquidity risk analysis within the operational day; stress testing of liquidity risk; and developing a financing plan in crisis situations.

The Law of Ukraine "On Currency and Currency Transactions" (Verkhovna Rada of Ukraine, 2018) was adopted, which became revolutionary for transition from a repressive system of currency regulation to a new liberal model "allowed everything that is not explicitly forbidden". Instead of 56 regulatory acts, only eight fundamental documents are currently in force. Business and the population have got a number of reliefs:

- Cancelled are:

- currency supervision for export-import operations up to UAH 150 thousand;

- individual licenses for foreign exchange transactions;

- $\quad$ sanctions in the form of termination of external economic activity;

- limit on early repayment of external liabilities;

- registration of external borrowings.

Allowed are:

- free opening of accounts of legal entities abroad;

- settlements in foreign currency on currency state bonds;

- currency swaps of banks with residents and non-residents; 
- import-export of cash foreign currency by legal entities;

- unlimited investment of banks in securities of investment grade;

- investments in currencies of the 2nd group of currency classifier into Ukraine.

- Increasing are:

- the deadline for settlement of export-import contracts rose to 365 days;

- limit on transfers abroad without opening an account for individuals rose to UAH 150 thousand per year;

- limit on the purchase of banking metals by individuals and legal entities rose to UAH 150 thousand per day.

- Simplified are:

- transactions on accounts of non-resident legal entities in banks of Ukraine;

- transfer of currency valuables across the border.

Within the framework of a new system of currency regulation, the National Bank of Ukraine also shifts from the system of total foreign exchange control over each operation to currency supervision based on the "more risks - more attention, less risk - less attention" principle. On February 7, 2019, a new procedure for applying measures of impact over banks was launched. It is more lenient to banks and takes into account the substantiality of a violation, and actions of the bank that led to violation.

It is also necessary to gradually abolish other restrictions, such as mandatory sale of currency earnings, deadlines for closing contracts, purchase of currency only under the obligation, investments of legal entities and individuals abroad. And Ukraine will become free for capital movements, which will improve the investment climate in the country, the inflow of foreign capital and sustainable economic growth.
Another reform carried out by the National Bank is that of corporate governance in banks. Why is this extremely important? Bronin (2018) found the following: "According to the research conducted by the methodology of clustering business models of Ukrainian banks that were withdrawn from the market during 2014-2018, poor corporate governance was one of the key causes of banks' bankruptcy."

The Law of Ukraine "On Amendments to Certain Legislative Acts of Ukraine on Simplification of Doing Business and Attracting Investment by Securities Issuers" (Verkhovna Rada of Ukraine, 2018) came into force. It has given banks the right to become private joint-stock companies; requirements for bank managers were reinforced; the competencies of the supervisory board were extended; quotas were increased and additional requirements for independent directors were set.

In 2018, the NBU approved the Methodological Recommendations on Corporate Governance in Ukrainian Banks, which meet the recommendations of the Basel Committee on Banking Supervision. The document contains requirements regarding the responsibilities, functions, composition and procedures of work of the bank's Board, formation, composition, powers and procedure of work of the committees of the bank's Board, role of the bank's Board in ensuring the effective functioning of the internal control system in the bank, introduction of an effective remuneration policy that will encourage employees to act in the interests of the bankand not resort to excessive risks, disclosure of information about corporate governance by the bank (NBU, 2018).

A fundamentally new Regulation on the Licensing of Banks was adopted, which regulates the transition from a formalistic to a risk-oriented approach in implementing the conciliation procedures (NBU, 2018c).

No less important is also to approve the Regulation on the Organization of Risk Management System in Ukrainian Banks and Banking Groups, which defines the list of main risks (credit risk, liquidity risk, interest rate risk, market risk, operational risk and compliance risk), for which the bank must necessarily conduct detection, measurement, monitoring, 


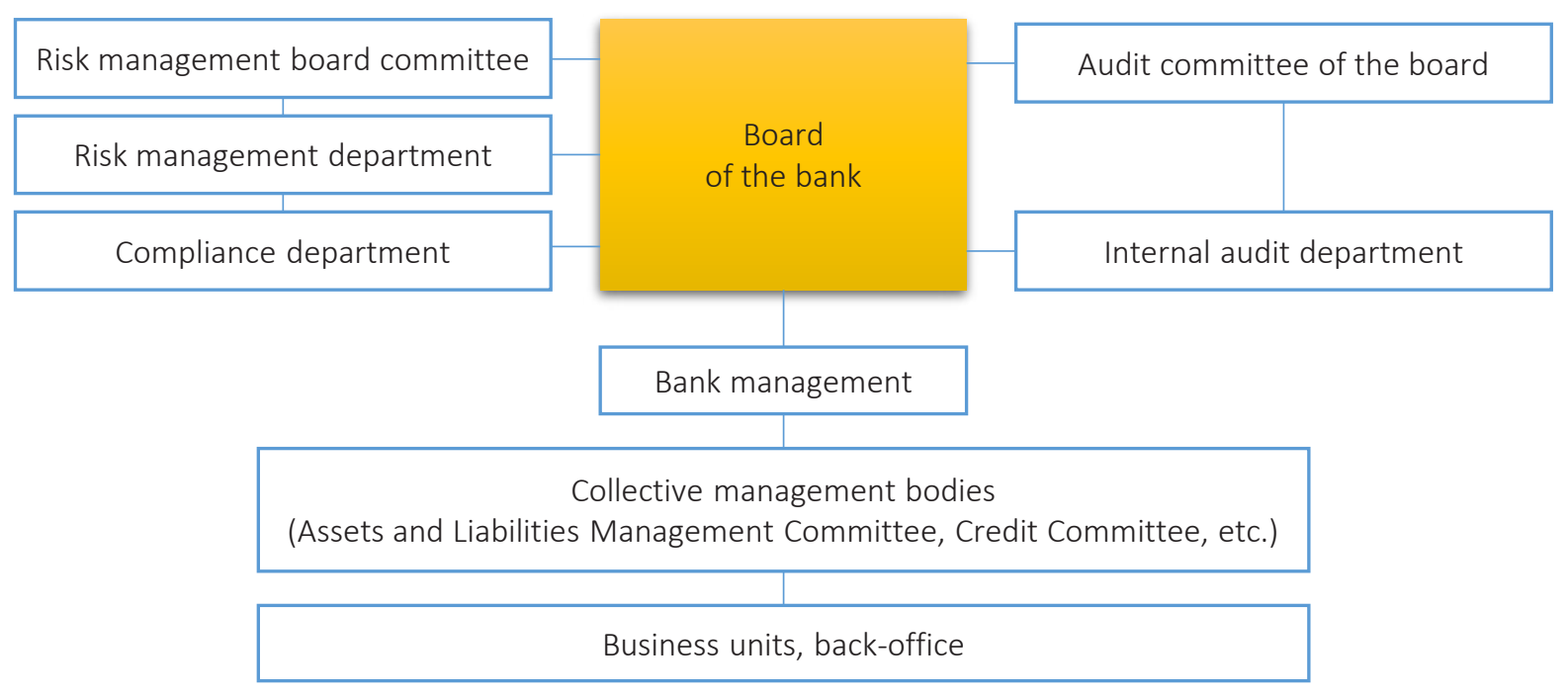

Figure 2. Organizational risk management system in the bank

control and reporting. In addition, the document provides for the extension of the powers of the bank's Board on the creation of a risk management system, building three lines of protection in the process of risk management (the first line - business-units, the second line - risk management and compliance, the third line internal audit), creating an organizational risk management system in the bank (Figure 2).

The National Bank of Ukraine is constantly improving the standards of public information disclosure by banks. Investors, customers, banking market participants from now on have more opportunities to analyze the financial condition of Ukrainian banks. In 2018, all Ukrainian banks for the first time in history have disclosed their results of asset quality assessment and stress testing.

The National Bank itself is also becoming more open and transparent. Its key activities are increasing communication efficiency regarding the NBU mandate, goals, nature, logic, plans and policy implications, providing all interested persons with an access to the information necessary for making financial decisions.
It is believed that the next steps of the National Bank of Ukraine in the reform of corporate governance should be:

- legislative definition of the "key person of the bank" concept and inclusion of key persons in the list of insiders;

- increasing the importance of risk management, compliance and internal audit departments, improving the requirements for the heads of these departments, introduction of preliminary approval of candidates for positions of heads of these units in the NBU and giving the NBU the right to demand the replacement of heads of those departments in case of their non-compliance with the requirements;

- introducing changes into the procedure for acquisition and increase of substantial participation in banks;

- establishing additional requirements for the Board members;

- expanding measures of influence on the bank owners. 


\section{CONCLUSION}

In conclusion, the comparative assessment of Basel II and Basel III allowed the detection of similarities and differences as well as benefits and shortcomings of both regimes, which provides an opportunity to rectify their drawbacks.

Based on the conducted research it was found that at the present stage the banking sector of Ukraine is exposed to the following systemic risks:

- state monopoly in the banking system;

- a large proportion of non-performing assets;

- weak protection of the creditors' rights;

- high dollarization;

- $\quad$ short-term funding base of banks; large maturity gaps between assets and liabilities;

- rapid growth of consumer lending; reduction of corporate lending;

- inflow of assets and operations into the non-banking financial sector.

To confront these challenges and ensure financial stability in the country in accordance with the Basel Committee on Banking Supervision recommendations, it is necessary to reform the banking legislation of Ukraine by introducing new principles, standards and macroprudential tools.

In 2018-2019, the National Bank of Ukraine made many steps towards reforming the banking sector. The new liquidity standard, Liquidity Coverage Ratio LCR, was introduced. Among the new capital instruments, in the near future, the buffer of capital conservation and the leverage ratio will be launched. The National Bank has shifted to a new bank evaluation process in conducting the banking supervision "Supervisory review and evaluation process", which had a positive impact on defining of a single strategy for banking supervision. Another innovation was the annual assessment of banks' stability, and for the largest banks - stress testing. As a result of stress testing in 2018, the banking sector is sufficiently capitalized under condition of the absence of macroeconomic shocks. In 2019, the key risk is the scenario of a deterioration in the quality of the consumer loan portfolio, which is significantly increasing over the recent years.

In 2018, the Ukrainian banking system shifted to the new international financial reporting standard, IFRS 9, which introduced a new model for assessing credit losses - not actually incurred, but expected on the basis of potential risks. The Law of Ukraine "On Currency and Foreign Exchange Transactions" replaced the old repressive system of currency regulation to a more liberal; as a result, business and the population have got an opportunity to carry out currency transactions more freely. Extremely important directions of reforming the banking system of Ukraine are improving corporate governance, enhancing the risk management system in banks, raising the standards of disclosure of public information by banks.

In the nearest future, the following steps need to be taken within the program of reforming the Ukrainian banking system:

- to develop a method of calculation and introduce Net Stable Funding Ratio (NSFR);

- to intensify the risk-oriented approach in the banking supervision process;

- to introduce requirements for organization of non-performing asset management process;

- to further remove restrictions on foreign currency operations; 
- to reinforce the requirements for the collective suitability of the Board and management of the bank;

- to improve approaches to building the risk-management in banks;

- to update the requirements for the internal control system in banks; improve the internal systems of financial monitoring of banks;

- to improve the quality of public information disclosure by banks; improve the licensing rules of non-banking financial institutions.

\section{REFERENCES}

1. Allen, F., \& Gale, D. (2000). Bubbles and crises. The Economic Journal, 110(460), 36-56. https:// doi.org/10.1111/1468-0297.00499

2. Altman, E., \& Sabato, G. (2005). Effects of the New Basel capital accord on bank capital requirements for SMEs. Journal of Financial Services Research, 28(1), 15-42. https://doi.org/10.1007/s10693005-4355-5

3. Angelini, P., Clerc, L., Curdia, V., Gambacorta, L., Gerali, A., Locarno, A., ..., \& Vlcek, J. (2011). Basel III: Long-term impact on economic performance and fluctuations (BIS Working Paper N. 338). Retrieved from https://www.bis.org/publ/ work338.pdf

4. Barth, J., Caprio, J., \& Levine, R. (2001). Banking systems around the globe: Do regulations and ownership affect performance and stability? In F. Mishkin (Ed.), Prudential Supervision: What Works and What Doesn't (pp. 31-88). University of Chicago Press. Retrieved from https://pdfs.semanticscholar. org/a552/daf365749b4abd05a59186150a95a5195c82.pdf

5. Basel Committee on Banking Supervision. (2013). Basel III: The Liquidity Coverage Ratio and liquidity risk monitoring tools. Retrieved from https://www.bis.org/ publ/bcbs238.pdf

6. Basel Committee on Banking Supervision. (2014). Basel III: The net stable funding ratio. Retrieved from https://www.bis.org/bcbs/ publ/d295.pdf
7. Basel Committee on Banking Supervision. (2018). Consultative Document: Revisions to the minimum capital requirements for market risk. Retrieved from https://www.bis.org/bcbs/publ/ d436.pdf

8. Basel Committee on Banking Supervision. (2019). Minimum capital requirements for market risk. Retrieved from https://www. bis.org/bcbs/publ/d457.pdf

9. Benford, J., \& Nier, E. (2007). Monitoring cyclicality of Basel II capital requirements (Financial Stability Paper No. 3). Bank of England. Retrieved from https:// www.bankofengland.co.uk/-/ media/boe/files/financial-stabilitypaper/2007/monitoring-cyclicality-of-basel-ii-capital-requirements. pdf

10. Blundell-Wignall, A., \& Atkinson, P. (2010). Thinking beyond Basel III: Necessary solutions for capital and liquidity. OECD Journal: Financial Market Trends, 2010(1), 9-33. https://doi.org/10.1787/fmt2010-5km7k9tpcjmn

11. Bronin, O. V. (2018). Ukrayinski banky v umovakh kryzy: biznesmodeli, shcho pryzvely do bankrutstva [Ukrainian banks in a crisis: business models that have led to bankruptcy] (In Ukrainian). Investytsii: praktyka ta dosvid - Investment: practice and experience, 22(11), 32-37. https://doi.org/10.32702/23066814.2018.22.32

12. EBA. (2018). Guidelines on stress testing. Retrieved from https://eba. europa.eu/regulation-and-policy/ supervisory-review-and-evaluation-srep-and-pillar-2/guidelineson-stress-testing2

13. Flamee, M., \& Windels, P. (2009). Restructuring financial sector supervision: Creating a level playing field. The Geneva Papers on Risk and Insurance. Issues and Practice, 34(1), 9-23. https://doi. org/10.1057/gpp.2008.36

14. Goodhart, C. (2018). The Changing Fortunes of Central Banking. In P. Hartmann, H. Huang, \& D. Schoenmaker (Eds.), The Changing Fortunes of Central Banking (pp. 376-390). Cambridge: Cambridge University Press. https://doi. org/10.1017/9781108529549.022

15. Heyets, V. (2016). 25 years of transformations. What next? Ekonomika i prognozuvanna, 2, 5-6. https://doi.org/10.15407/ eip2016.02.005

16. IMF. (2018). Global Financial Stability Report. A Decade after the Global Financial Crisis: Are We Safer? Retrieved from https://www. imf.org/en/Publications/GFSR/Issues/2018/09/25/Global-FinancialStability-Report-October-2018

17. Kozmenko, S., \& Vasyleva, T. (2009). World financial crisis: causes, consequences, ways of overcoming. Sumy: Business Perspectives. Retrieved from https:// businessperspectives.org/books/ world-financial-crisis-causesconsequences-ways-of-overcoming

18. National Bank of Ukraine (NBU). (2017). Polozhennia pro zdiysnennia otsinky stiikosti bankiv i bankivskoi systemy Ukrainy [Regulation on the implementation 
of the assessment of the stability of banks and the banking system of Ukraine] (In Ukrainian). Retrieved from https://zakon.rada.gov.ua/ laws/show/v0141500-17

19. National Bank of Ukraine (NBU). (2018a). Stratehiia makroprudentsiynoi polityky [Macroprudential Policy Strategy] (In Ukrainian). Retrieved from https://bank.gov.ua/doccatalog/ document?id=83019081

20. National Bank of Ukraine (NBU). (2018b). Pro zaprovadzhennia koefitsiienta pokryttia likvidnistiu (LCR) [On the Introduction of $\mathrm{Li}$ quidity Coverage Ratio (LCR)] (In Ukrainian). Retrieved from https:// zakon.rada.gov.ua/laws/show/ v0013500-18

21. National Bank of Ukraine (NBU). (2018c). Polozhennia pro litsenzuvannia bankiv [Regulation on the licensing of banks] (In Ukrainian). Retrieved from https:// zakon.rada.gov.ua/laws/show/ v0149500-18
22. National Bank of Ukraine (NBU). (2018d). Polozhennia pro orhanizatsiiu systemy upravlinnia ryzykamy $v$ bankakh Ukrainy ta bankivskykh hrupakh [Regulation on the organization of risk management system in Ukrainian banks and banking groups] (In Ukrainian). Retrieved from https:// zakon.rada.gov.ua/laws/show/ v0064500-18

23. Ruthenberg, D., \& Landskroner, Y. (2008). Loan pricing under Basel II in an imperfectly competitive banking market. Journal of Banking \& Finance, 32(12), 2725-2733. https:// doi.org/10.1016/j.jbankfin.2008.07.009

24. Thakor, A. (1996). Capital requirements, monetary policy, and aggregate bank lending: theory and empirical evidence. The Journal of Finance, 51(1), 279-324. https://doi. org/10.1111/j.1540-6261.1996. tb05210.x
25. The International Accounting Standards Board (IASB). (2012). Mizhnarodnyi standart finansovoi zvitnosti 9 (MSFZ 9). Finansovi instrumenty [International Financial Reporting Standard 9 (IFRS 9) Financial instruments] (In Ukrainian). Retrieved from https://zakon.rada. gov.ua/laws/show/929_016

26. Van den Henvel, S. (2002). Does bank capital matter for monetary transmission? Economic Policy Review, 8(1), 259-265. Retrieved from https://www.newyorkfed. org/medialibrary/media/research/epr/02v08n1/0205vand. pdf

27. Verkhovna Rada of Ukraine. (2018). Zakon Ukrainy Pro Valiutu i Valiutni Operatsii [The Law of Ukraine on Currency and Currency Operations] (In Ukrainian). Retrieved from https://zakon.rada.gov.ua/laws/ show/2473-19 